\title{
Communal Motivation
}

\author{
Bonnie M. Le ${ }^{1}$ \& Emily A. Impett ${ }^{2}$ \\ University of Toronto ${ }^{1}$ \\ University of Toronto Mississauga²
}

In press at Macmillan Encyclopedia of Intimate and Family Relationships

The authors acknowledge support from a Social Sciences and Humanities Research

Council (SSHRC) Banting Postdoctoral Fellowship awarded to B. M. Le and a SSHRC Insight Grant awarded to E. A. Impett. 


\section{Communal Motivation}

In close relationships, people's outcomes become highly intertwined, or interdependent, over time and across contexts (Clark and Mills 2011; Kelley and Thibaut 1978; Rusbult and Van Lange 2003). For example, young children rely on care from their parents as they grow and develop, and as they become older themselves, they often provide care and companionship to their aging parents. Friends provide emotional support to one another in times of need and share in one another's joys in times of accomplishment. Romantic partners provide affection and physical intimacy to each other in ways unmatched by other relationship partners. Given that people rely on their relationship partners to meet many of their needs and desires, communal motivation, or care for the welfare of others, is an important component of personal wellbeing and satisfying relationships (Le, Impett, Lemay, Muise, and Tskhay 2018). Here, the history of communal motivation research is reviewed; the role of communal motivation in building and maintaining relationships described; and the emotional expressions and reactions linked to communal motivation explained.

\section{History and Definitions}

Theories on communal motivation in relationships arose in the 1970s when Margaret Clark and Judson Mills (1979) argued that the norms that govern behavior could vary by relationship context. At this time, many theories of behavior were economic or equity based. However, Clark and Mills (1979) proposed that relationships can be either communal or exchange in nature. They posited that communal relationships are characterized by providing benefits to partners based on need whereas exchange relationships are characterized by providing benefits in a tit-for-tat, 
or one-for-one, fashion. This distinction set the bedrock for research that has gone on to show how communal, versus exchange, norms for providing benefits predict greater interpersonal attraction, intimacy, and satisfaction when a close relationship is desired (Clark and Mills 2011).

Given the relative benefits of communal, relative to exchange, approaches to relationships, researchers began to focus on individual variability in communal orientations, as well as implications for personal and relationship outcomes. First, researchers showed how communal orientation-or the motivation to care for the welfare of others and the desire for reciprocal care_predicts helping strangers in need (Clark, Ouellette, Powell, and Milberg 1987). Further, communal strength—or the motivation to care for a specific person through investment of time, effort, or moneypredicts receiving and providing help amongst friends and more satisfying marital relationships (Mills, Clark, Ford, and Johnson 2004).

As the field of close relationships grew during the second half of the twentieth century (Berscheid 1999; Reis 2007), so have theories of communal motivation. In a recent integrative review, Le, Impett, Lemay, Muise, and Tskhay (2018) sought to integrate theory on different forms of communal motivation. As shown in Table 1, communal motivation can vary based on a number of aspects. First, people may be communally motivated for others generally or for specific relationship partners, such as a friend, romantic partner, parent, or child (Le and Impett 2015; Mills, Clark, Ford, and Johnson 2004); that is, people may be motivated to care for others indiscriminately, or they may target or reserve their care for specific people. Further, people may be communally motivated in ways that account for their own desires and needs (Clark and 
Mills 2011; Clark, Ouellete, Powell, and Milberg 1987) or in ways that neglect them (Helgeson and Fritz 1998). In other words, people may care for others while desiring mutual care, or they may provide care in ways that are devoid of agency and concern for their own needs. More recently, research has shown that people may also be communally motivated in specific relationship domains, such as sexuality (Muise, Impett, Kogan, and Desmarais 2013; Muise and Impett 2016). Importantly, these different forms of communal motivation have unique personal and relationship implications, which are discussed below.

\section{Building and Maintaining Relationships}

Communal motivation can help build relationships. For instance, when desiring a close relationship, people are more attracted to others who provide benefits based on needs rather than those who provide benefits only in direct exchange for the ones they receive (Clark and Mills 1979). Further, general communal motivation may prompt people to help strangers, which in turn contributes to close relationship initiation (Clark et al. 1987). In addition, communally motivated people can be biased in ways that help build their relationships. More specifically, people who are highly communally motivated construct satisfying relationships by projecting their own communal motivation onto their partners (Lemay and Clark 2008; Lemay, Clark, and Feeney 2007). In turn, they engage in more self-disclosure, evaluate their partners more positively, and perceive their partners to also be communally motivated and supportive; thus, communally motivated people show high communal motivation to their partners over time and experience more satisfying relationships (Lemay and Clark 2008; Lemay, Clark, and Feeney 2007). 
In addition to helping initiate and build relationships, communal motivation may contribute to relationship maintenance by supporting the well-being of both partners. Across relationships, including those between parents and children, friends, and romantic partners, meta-analytic evidence from one hundred studies demonstrated that communal motivation for others generally, as well as for specific relationship partners, is linked to greater personal and relationship well-being for both the self and partners (Le, Impett, Lemay, Muise, and Tskhay 2018). These findings can be explained by work showing that general and partner-specific communal motivation are linked to increased positive emotions in daily life (Le, Impett, Kogan, Webster, and Cheng 2012), greater feelings of authenticity when caring for others (Kogan et al. 2010; Le and Impett 2015), and decreased perceptions of costs involved in caring for a partner (Day, Muise, Joel, and Impett 2015). Regarding gender differences, although men may experience barriers, devalue, and have misconceptions about taking on communal roles (Block, Croft, and Schmader 2018; Croft, Schmader, and Block 2015; Van Grootel, Van Laar, Meeussen, Schmader, and Sczesny 2018), the well-being benefits linked to communal motivation are observed in both men and women (Le, Impett, Lemay, Muise, and Tskhay 2018). Importantly, communal motivation is linked to greater personal well-being for the self and relationship partners only to the extent that people do not lose sight of their own needs. Indeed, while communal motivation that is unmitigated by self-concern is linked to more satisfying relationships through high degrees of care, it compromises personal well-being through feelings of distress, self-neglect, and over-involvement in others' problems (Fritz and Helgeson 1998). 


\section{Emotional Expressions and Reactions}

In order to provide support, relationship partners must understand when the other person is in need and express care accordingly. An important avenue for doing so is through emotional expression—often in order to show a need—and emotional reaction-in order to respond to a need. Communally motivated individuals express and react to emotions in ways that help facilitate the communication of, and response to, personal and relationship needs.

In regards to emotional expression, people are more likely to express emotions when they are communally motivated and perceive their partners to be communal (Clark, Armentano, Boothby, and Hirsch 2017; Clark and Finkel 2005; Clark and Taraban 1991; Von Culin, Hirsch, and Clark 2018). In particular, people are comfortable expressing a range of emotions to a perceived communal partner that may communicate their needs and desires—including happiness sadness, disgust, and anger (Clark and Taraban 1991; Von Culin, Hirsch, and Clark 2018). In addition, when people are communally motivated themselves, they are more comfortable expressing emotions that signal vulnerability, or the need for support, including hurt, guilt, fear, and anxiety, especially when they perceive their partner to be communal (Clark and Finkel 2005; Von Culin, Hirsch, and Clark 2018).

People also react more positively to another person's emotional expressions when they are communally motivated. For instance, those who desire a communal relationship prefer to talk about emotional topics and like a partner more when this partner expresses happiness, sadness, or irritability (Clark and Taraban 1991). Further, communally motivated people respond in supportive ways when observing emotional 
expressions in a partner. They are more likely to empathize with and feel similar emotions as their partner, such as feeling sadness when a partner is sad or sharing in a partner's joys and accomplishments (Clark, Armentano, Boothby, and Hirsch 2017; Mills and Clark 2001). Communally motivated people may also support their partners by helping them regulate their emotions (Clark, Armentano, Boothby, and Hirsch 2017). Finally, communal motivation is not always linked to relationally adaptive emotional responses. When a person's communal care is not mitigated by a sense of concern for his or her own needs, his or her emotional reactions to others can be personally draining. For instance, they are more likely to experience personal distress from a partner's troubles (Fritz and Helgeson 1998) and have difficulty accepting support from others, undermining the benefits they may receive through interpersonal regulation (Fritz and Helgeson 1998).

\section{Conclusion}

In interdependent relationships, people rely on one another for support and fulfillment. Since the 1970s, research has uncovered how communal motivation to care for the welfare of others can serve as the foundation for constructing supportive relationships. Communal motivation to care for others, especially when it is accompanied by self-oriented concern, can help initiate relationships, promote responsive behaviors, sustain the well-being of both partners, and facilitate emotionally expressive and enriching relationships. 


\section{Bibliography}

Berscheid, Ellen. 1999. "The Greening of Relationship Science." American Psychologist 54 (4): 260-266. http://doi.org/10.1037/0003-066X.54.4.260.

Block, Katharina, Croft, Alyssa, and Schmader, Toni. 2018. "Worth Less?: Why Men (and Women) Devalue Care-Oriented Careers." Frontiers in Psychology, 9, 1353.

Clark, Margaret S., Lucylle A. Armentano, Erica J. Boothby, and Jennifer L. Hirsch. 2017. "Communal Relational Context (or Lack Thereof) Shapes Emotional Lives." Current Opinion in Psychology 17 (October): 176-183. http://doi.org/10.1016/j.copsyc.2017.07.023.

Clark, Margaret S.,, and Eli J. Finkel. 2005. "Willingness to Express Emotion: The Impact of Relationship Type, Communal Orientation, and Their Interaction." Personal Relationships 12 (2): 169-180. http://doi.org/10.1111/j.13504126.2005.00109.

Clark, Margaret S., and Judson Mills. 1979. "Interpersonal Attraction in Exchange and Communal Relationships." Journal of Personality and Social Psychology 37 (1): 12-24. http://doi.org/10.1037/0022-3514.37.1.12.

Clark, Margaret S.,and Judson R. Mills. 2011. "A Theory of Communal (and Exchange) Relationships." Handbook of Theories of Social Psychology, edited by Paul A. M. Van Lange, Arie W. Kruglanski, and E. Tory Higgins, 2:232-250. London: Sage.

Clark, Margaret S., Robert Ouellette, Martha C. Powell, and Sandra Milberg. 1987. "Recipient's Mood, Relationship Type, and Helping." Journal of Personality and Social Psychology 53 (1): 94-103. http://doi.org/10.1037/0022-3514.53.1.94. Clark, Margaret S., and CarolynTaraban. 1991. "Reactions to and Willingness to 
Express Emotion in Communal and Exchange Relationships." Journal of Experimental Social Psychology 27 (4): 324-336. http://doi.org/10.1016/00221031(91)90029-6.

Croft, Alyssa, Toni Schmader, and Katharina Block. 2015. "An Underexamined Inequality: Cultural and Psychological Barriers to Men's Engagement with Communal Roles." Personality and Social Psychology Review 19 (4): 343-370. http://doi.org/10.1177/1088868314564789.

Day, Lisa C., Amy Muise, Samantha Joel, and Emily A. Impett. 2015. "To Do It or Not to Do It? How Communally Motivated People Navigate Sexual Interdependence Dilemmas." Personality and Social Psychology Bulletin 41 (6): 791-804. http://doi.org/10.1177/0146167215580129.

Fritz, Heidi L., and Vicki S. Helgeson. 1998. "Distinctions of Unmitigated Communion from Communion: Self-Neglect and Overinvolvement with Others." Journal of Personality and Social Psychology 75 (1): 121-140. http://doi.org/10.1037/00223514.75.1.121.

Helgeson, Vicki S., and Heidi L. Fritz. 1998. "A Theory of Unmitigated Communion." Personality and Social Psychology Review 2 (3): 173-183. http://doi.org/10.1207/s15327957pspr0203_2.

Kelley, Harold H., and John W. Thibaut. 1978. Interpersonal Relations: A Theory of Interdependence. New York: Wiley.

Kogan, Aleksandr, Emily A. Impett, Christopher Oveis, Bryant Hui, Amie M. Gordon, and Dacher Keltner. 2010. "When Giving Feels Good: The Intrinsic Benefits of Sacrifice in Romantic Relationships for the Communally Motivated." Psychological 
Science 21 (12): 1918-1924. http://doi.org/10.1177/0956797610388815.

Le, Bonnie M., and Emily A. Impett. 2015. "The Rewards of Caregiving for Communally Motivated Parents." Social Psychological and Personality Science 6 (7): 758-765. http://doi.org/10.1177/1948550615581498.

Le, Bonnie M., Emily A. Impett, Aleksandr Kogan, Gregory D. Webster, and Cecilia Cheng. 2012. "The Personal and Interpersonal Rewards of Communal Orientation." Journal of Social and Personal Relationships 30 (6): 694-710. http://doi.org/10.1177/0265407512466227.

Le, Bonnie M., Emily A. Impett, Edward P. Lemay, Amy Muise, Konstantin O.Tskhay. 2018. "Communal Motivation and Well-Being in Interpersonal Relationships: An Integrative Review and Meta-Analysis." Psychological Bulletin 144 (1): 1-25. http://doi.org/10.1037/bul0000133.

Lemay, Edward P., and Margaret S. Clark. 2008. "How the Head Liberates the Heart: Projection of Communal Responsiveness Guides Relationship Promotion." Journal of Personality and Social Psychology 94 (4): 647-671. http://doi.org/10.1037/00223514.94.4.647.

Lemay, Edward P., Margaret S. Clark, and Brooke C. Feeney. 2007. "Projection of Responsiveness to Needs and the Construction of Satisfying Communal Relationships." Journal of Personality and Social Psychology 92 (5): 834-853. http://doi.org/10.1037/0022-3514.92.5.834.

Lemay, Edward P., and Angela M. Neal. 2012. "The Wishful Memory of Interpersonal Responsiveness." Journal of Personality and Social Psychology 104 (4): 653-672. http://doi.org/10.1037/a0030422. 
Mills, Judson, and Margaret S. Clark. 2001. "Viewing Close Romantic Relationships as Communal Relationships: Implications for Maintenance and Enhancement." In Close Romantic Relationships: Maintenance and Enhancement, edited by John Harvey and Amy Wenzel, 13-26. Mahwah, NJ: Erlbaum.

Mills, Judson, Margaret S. Clark, Thomas E. Ford, and Melanie Johnso. 2004.

"Measurement of Communal Strength." Personal Relationships 11 (2): 213-230. http://doi.org/10.1111/j.1475-6811.2004.00079.

Muise, Amy, Sophie Bergeron, Emily A. Impett, and Natalie O. Rosen. 2017. "The Costs and Benefits of Sexual Communal Motivation for Couples Coping with Vulvodynia." Health Psychology 36 (8): 819-827. http://doi.org/10.1037/hea0000470.

Muise, Amy, and Emily A. Impett. 2016. "Applying Theories of Communal Motivation to Sexuality." Social and Personality Psychology Compass 10 (8):455-467. http://doi.org/10.1111/spc3.12261.

Muise, Amy, Emily A. Impett, Aleksandr Kogan, and Serge Desmarais. 2013. "Keeping the Spark Alive: Being Motivated to Meet a Partner's Sexual Needs Sustains Sexual Desire in Long-Term Romantic Relationships." Social Psychological and Personality Science 4 (3): 267-273. http://doi.org/10.1177/1948550612457185.

Reis, Harry T. 2007. "Steps toward the Ripening of Relationship Science." Personal Relationships 14 (1): 1-23. http://doi.org/10.1111/j.1475-6811.2006.00139.

Rusbult, Caryl E., and Paul A. M. Van Lange. 2003. "Interdependence, Interaction, and Relationships." Annual Review of Psychology 54 (1): 351-375. http://doi.org/10.1146/annurev.psych.54.101601.145059.

Van Grootel, Sanne Van, Van Laar, Colette, Meeussen, Loes, Schmader, Toni, and 
Sczesny, Sabine (2018). "Uncovering Pluralistic Ignorance to Change Men's Communal Self-Descriptions, Attitudes, and Behavioral Intentions." Frontiers in Psychology, 9, 1344.

Von Culin, Katharine R., Jennifer L. Hirsch, and Margaret S. Clark. 2018. "Willingness to Express Emotion Depends upon Perceiving Partner Care." Cognition and Emotion 32 (3): 641-650. http://doi.org/10.1080/02699931.2017.1331906. 
Table 1

Definitions and Forms of Communal Motivation

\begin{tabular}{|c|c|c|c|}
\hline $\begin{array}{l}\text { Forms of Communal } \\
\text { Motivation }\end{array}$ & Definition & Target of Care & Measurement \\
\hline General & $\begin{array}{l}\text { Care for the welfare of others and } \\
\text { desired care for the self }\end{array}$ & Others generally & $\begin{array}{l}\text { Communal Orientation Scale } \\
\text { (Clark, Oullette, Powell, and Milberg } \\
\text { 1987) }\end{array}$ \\
\hline Partner-Specific & $\begin{array}{l}\text { Care for the welfare of a specific } \\
\text { relationship partner }\end{array}$ & $\begin{array}{l}\text { A specific relationship partner, } \\
\text { such as a child, friend, romantic } \\
\text { partner, parent, or co-worker }\end{array}$ & $\begin{array}{l}\text { Communal Strength Scale } \\
\text { (Mills, Clark, Ford, and Johnson 2004) }\end{array}$ \\
\hline Unmitigated & $\begin{array}{l}\text { Care for the welfare of others which is } \\
\text { devoid of agency and } \\
\text { acknowledgement of personal needs }\end{array}$ & Others generally & $\begin{array}{l}\text { Unmitigated Communion Scale } \\
\text { (Fritz and Helgeson 1998) }\end{array}$ \\
\hline
\end{tabular}

Note. For an updated and more reliable measure of partner-specific communal motivation by Lemay \& Neal, 2013 , see Appendix A of Le, Impett, Lemay, Muise, and Tskhay (2018). Partner-specific communal motivation can also be assessed in specific domains such as sexuality (see Muise, Impett, Kogan, and Desmarais 2013). Unmitigated communal motivation, while usually assessed for others generally (Fritz and Helgeson 1998), can be adapted to target specific partners and domains (for an example, see Muise, Bergeron, Impett, and Rosen 2017). 